Check for updates

Cite this: Nanoscale Adv., 2019, 1, 807

\title{
Galactose:PEGamine coated gold nanoparticles adhere to filopodia and cause extrinsic apoptosis $\uparrow$
}

\author{
Konstantina Tzelepi, ${ }^{a}$ Cristina Espinosa Garcia, ${ }^{\mathrm{b}}$ Phil Williams ${ }^{\mathrm{b}}$ and Jon Golding (D) *a
}

\begin{abstract}
Ultra-small gold nanoparticles, surface functionalised with a $50: 50$ ratio of a thiolated $\alpha$-galactose derivative and a thiolated hexaethylene glycol amine, are toxic to HSC-3 oral squamous carcinoma cells. Differences in nanoparticle toxicity were found to be related to the synthesis duration, with $1 \mathrm{~h}$ reaction nanoparticles being less toxic than $5 \mathrm{~h}$ reaction nanoparticles. The ligand density decreased with longer reaction time, although the size, charge and ligand ratio remained similar. The concentration of sodium borohydride in the reaction decreased logarithmically over $5 \mathrm{~h}$ but remained within a concentration range sufficient to desorb weakly bound ligands, possibly explaining the observed gradual decrease in ligand density. Nanoparticle toxicity was abrogated by inhibition of either caspase 3/7 or caspase 8 , but not by inhibition of caspase 9 , consistent with extrinsic apoptosis. Electron microscopic analysis of cellular uptake demonstrated predominantly cytoplasmic localization. However, when energy-dependent transport was inhibited, by lowering the temperature to $4{ }^{\circ} \mathrm{C}$, a remarkable adhesion of nanoparticles to filopodia was observed. Inhibition of filopodial assembly with a fascin inhibitor prevented nanoparticle adhesion to HSC-3 cells at $4{ }^{\circ} \mathrm{C}$, while fascin inhibition at $37^{\circ} \mathrm{C}$ resulted in less cytoplasmic uptake. More adhesion to HSC-3 filopodia was seen with the higher toxicity $5 \mathrm{~h}$ reaction time nanoparticles than with the $1 \mathrm{~h}$ nanoparticles. By including two further cell types ( $\mathrm{HaCaT}$ keratinocytes and hCMEC/D3 endothelial cells), a pattern of increasing toxicity with filopodial binding of $5 \mathrm{~h}$ reaction nanoparticles became apparent.
\end{abstract}

Received 3rd October 2018

Accepted 9th November 2018

DOI: $10.1039 / c 8 n a 00270 c$

rsc.li/nanoscale-advances into kidney and brain endothelial cells, predominantly by energy-dependent mechanisms. ${ }^{13}$ These AuNPs show selective toxicity toward HSC-3 skin cancer cells, compared to a normal keratinocyte cell line (HaCaT) and this toxicity was caspase 3/7dependent and could be prevented by antioxidants. ${ }^{2}$

In order to examine the interaction and toxicity of $\alpha$-galactose:PEGamine AuNPs with HSC-3 cancer cells in more detail, we analysed AuNP distribution on the cell surface, and within the cytoplasm and nucleus. Two types of AuNPs were tested, which differed only in their synthesis time. One was reacted with sodium borohydride for $1 \mathrm{~h}$ (short synthesis) and the other was reacted for $5 \mathrm{~h}$ (long synthesis). We find that the shorter synthesis time AuNPs show less binding to filopodia and are less toxic.

\section{Materials and methods}

\section{Nanoparticle synthesis}

2-Thioethyl $\alpha$-D-galactopyranoside as the disulphide dimer $(\alpha$ galactose) and 1-thiohexaethylene glycol-17-ammonium acetate (PEG-amine) (both from GalChimia, Spain) were mixed together in a $50: 50$ molar ratio with $\mathrm{HAuCl}_{4}$ in Milli-Q water with a 3fold molar excess of total ligands to gold and adjusted to $\mathrm{pH} 12$ with $2 \mathrm{M} \mathrm{NaOH}$. The mixture was stirred constantly and reduced by adding $\mathrm{NaBH}_{4}$ to $90 \mathrm{mM}$ and samples removed after either $1 \mathrm{~h}$ or $5 \mathrm{~h}$. AuNPs were then purified from unreacted ligands and 
reactants via five rounds of spin washing with excess Milli-Q water using an Amicon $10 \mathrm{kDa}$ ultrafiltration device. AuNPs were resuspended in water to $2 \mathrm{mg} \mathrm{ml}^{-1}[\mathrm{Au}]$ and stored in amber vials at $4{ }^{\circ} \mathrm{C}$. Note that all AuNP concentrations stated in this work are based on gold content.

\section{Sodium borohydride assay}

The hydrolytic loss of $\mathrm{NaBH}_{4}$ during the AuNP synthesis reaction was monitored by the 2,4,6-trinitrobenzenesulfonic acid (TNBS) assay. ${ }^{14}$ Milli-Q water was adjusted to $\mathrm{pH} 12$ with $0.2 \mathrm{M}$ $\mathrm{NaOH}$. To a $10 \mathrm{ml}$ portion of this, $\mathrm{NaBH}_{4}$ was added to achieve a final concentration of $90 \mathrm{mM}$. To a $5 \mathrm{ml}$ portion of the resulting $90 \mathrm{mM} \mathrm{NaBH}_{4}$ solution, $15 \mathrm{mg} \mathrm{HAuCl}_{4}$ and $39 \mathrm{mg}$ 5,5dithio-bis-(2-nitrobenzoic acid) were simultaneously added, corresponding to the molarities of gold and ligands used in a standard AuNP synthesis reaction (note that we had to replace the $\alpha$-galactose and PEG-amine disulphide ligands with another disulphide, since TNBS reacts with primary amines). Twenty microlitre aliquots of this reaction mixture were removed at intervals and added to $180 \mu \mathrm{l}$ of $\mathrm{pH} 12$ water in 96-well plastic plates. Finally, $20 \mu \mathrm{l}$ aliquots of the diluted samples were added to $200 \mu \mathrm{l}$ aliquots of freshly prepared $2 \mathrm{mM}$ TNBS in $\mathrm{pH} 12$ water. After $15 \mathrm{~min}$, the absorbance of the TNBS solution was measured at $470 \mathrm{~nm}$ using a FLUOstar Optima plate reader (BMG Labtech) and calibrated using a doubling dilution series of the $90 \mathrm{mM} \mathrm{NaBH}_{4}$ solution, treated in an identical way to the AuNP reaction.

\section{Nanoparticle physico-chemical characterization}

TEM. Samples were prepared by drop-coating films of the AuNP solutions on electrostatically discharged carbon-coated copper TEM grids and visualized on a JEM-1400 model EM instrument (JEOL, USA) operated at an accelerating voltage of 80 $\mathrm{kV}$ and $100000 \times$ magnification. Core sizes were calculated from TEM images using the automated particle analysis feature of Image J software and are reported as the mean and median values.

DLS/zeta potential. The hydrodynamic diameter and charge of AuNPs (500 $\mu \mathrm{g} \mathrm{ml}^{-1}$ ) were measured using a Zetasizer Nano ZSP (Malvern instruments). DLS measurements were made immediately in pH 7.4 PBS in a ZEN0040 cell, while zeta potential measurements were made in $20 \mathrm{mM}$ of phosphate buffer at pH 7 in a DTS1070 cell.

UV-vis absorbance. Two hundred microlitres of 100-400 $\mu \mathrm{g}$ $\mathrm{ml}^{-1}$ AuNP solutions in water were measured against a water blank in 96-well plates on a Labtech Spectrostar Nano spectrophotometer. Absorbance was measured between 280 and $800 \mathrm{~nm}$.

FPLC. $0.2 \mathrm{mg} \mathrm{ml}^{-1}$ AuNPs were incubated in PBS for $30 \mathrm{~min}$ at $37{ }^{\circ} \mathrm{C}$. Then $20 \mu \mathrm{g}$ AuNPs were run on an AKTA Pure FPLC system (GE Healthcare) with a Superdex 200 10/300 GL column at $0.5 \mathrm{ml} \mathrm{m^{-1 }}$ isocratic in PBS, using a $100 \mu \mathrm{l}$ injection loop and the absorbance monitored at $400 \mathrm{~nm}$.

${ }^{1} \mathbf{H}$-NMR. For each sample, $5 \mathrm{mg}$ of AuNPs were transferred into $\mathrm{D}_{2} \mathrm{O}$ using ultrafiltration (Amicon Ultra-4, MWCO $10 \mathrm{kDa}$ ). Three centrifugation steps were performed in $2 \mathrm{ml} \mathrm{D}_{2} \mathrm{O}$
(4700 rpm, $12 \mathrm{~min}$ ). After the last centrifugation step, AuNPs were transferred into Eppendorf tubes and dissolved with $0.3 \mathrm{M}$ $\mathrm{KCN} / 0.1 \mathrm{M} \mathrm{KOH}$ in $\mathrm{D}_{2} \mathrm{O}$ at $37{ }^{\circ} \mathrm{C}$ overnight. Samples were then centrifuged at $13000 \times g$ for $1 \mathrm{~min}$ to remove any insoluble material and analysed by ${ }^{1} \mathrm{H}-\mathrm{NMR}$ at $500 \mathrm{MHz}$ (Avance III HD, Bruker), using MestReNova software. The defining protons for the $\alpha$-galactose and PEGamine ligands were identified to resonate at $4.95 \mathrm{ppm}$ and $2.75 \mathrm{ppm}$, respectively. These correspond to the single anomeric proton of $\alpha$-galactose (NMR doublet) and the two $\mathrm{CH}_{2}$ protons proximal to the terminal $\mathrm{NH}_{2}$ group in the PEG-amine linker (NMR triplet).

HPLC. To quantify thiol ligands, $8 \mu \mathrm{l}$ of $0.5 \mathrm{mg} \mathrm{ml}^{-1}$ AuNP solution was mixed with $4 \mu \mathrm{l}$ of $50 \mathrm{mM}$ tris(2-carboxyethyl) phosphine hydrochloride in water for $10 \mathrm{~min}$ at $37{ }^{\circ} \mathrm{C}$ at $600 \mathrm{rpm}$. Then $28 \mu \mathrm{l}$ of $25 \mathrm{mM}$ Ellman's reagent in DMSO was added and incubated for a further $60 \mathrm{~min}$ at $37^{\circ} \mathrm{C}$ at $600 \mathrm{rpm}$. Samples were transferred to an HPLC vial and $10 \mu \mathrm{l}$ of each sample was injected into an Agilent 1260 Infinity HPLC machine with an Ascentis Express peptide ES-C18 column and an acetonitrile $/ 0.1 \%$ formic acid solvent gradient, with peak detection at $330 \mathrm{~nm}$. Pure ligands were similarly treated to determine retention times. The HPLC was additionally fitted with an Agilent 6120 Single Quad mass spectrometer to verify peak identities.

SEM-EDS. Three microlitres of $2 \mathrm{mg} \mathrm{ml}^{-1}$ AuNP solutions were dried onto aluminium stubs and analysed with a Zeiss Supra 55VP Field Emission Gun Scanning Electron Microscope (FEGSEM) at $20 \mathrm{kV}$. EDS analysis was performed with AZtec Energy software (Oxford Instruments). The stubs alone contained undetectable levels of gold and sulphur, $4.9 \%$ carbon and $0.5 \%$ oxygen. Weight $\%$ values for gold, sulphur, carbon and oxygen in the AuNP samples were determined. The calculation of the AuNP ligand density using the sulphur : gold ( $\mathrm{S}: \mathrm{Au}$ ) ratio is based on the assumption that each ligand on the AuNP surface carries a single $\mathrm{S}$ atom, while $\mathrm{Au}$ atoms constitute the AuNP core. The geometry of AuNPs is assumed to be spherical.

\section{Cell culture}

HSC-3 squamous carcinoma cells were purchased from the American Type Culture Collection. HaCaT cells were a gift from Erik Walbeem, Erasmus Medical Centre, Rotterdam. Cells were cultured in low glucose $\left(1 \mathrm{~g} \mathrm{l}^{-1}\right)$ DMEM media (Gibco) supplemented with $10 \%$ FBS (Sigma-Aldrich) and $1 \%$ penicillin/ streptomycin in a humidified incubator at $37{ }^{\circ} \mathrm{C}$ with $5 \% \mathrm{CO}_{2}$. Cells were grown in T-75 culture flasks to about $80 \%$ confluency before passage.

\section{Clonogenic assay}

Cells were seeded at 300 cells per well in 24-well plates and allowed to adhere overnight. The next day, cells were exposed to AuNPs for $3 \mathrm{~h}$ and then washed in fresh medium. We previously demonstrated that $3 \mathrm{~h}$ incubation was optimal for clonogenic assay and uptake studies using these types of sugar:PEGamine AuNPs. ${ }^{2}$ Cells were left to grow for 6 days to form colonies and were then stained and fixed with $2 \%$ methylene blue in $50 \%$ ethanol. Experiments were repeated three times, each with 
technical triplicates (total $n=9$ ). Images of stained plates were captured using a G:Box Chemi XX6 gel documentation system with GeneSys v1.4.6 software (Syngene). Colonies containing $>50$ cells were quantified using GeneTools v.4.03 software (Syngene) and expressed as percent of controls. Automated counts were verified by eye. $\mathrm{IC}_{50}$ values were estimated from logarithmic plots of AuNP concentration versus percent of control colonies.

\section{Cellular uptake and distribution}

Cellular uptake was quantified by ICP-MS and TEM.

ICP-MS. Cells were seeded at 30000 cells per well overnight in 24-well plates. At this density, most cells were isolated from their neighbours. Cells were then incubated with AuNPs for $3 \mathrm{~h}$ at a final concentration of $10 \mu \mathrm{g} \mathrm{ml}{ }^{-1}$, in triplicate. Cells were washed 3 times in medium, trypsinised and spin washed twice at $2000 \mathrm{rpm}$ in $10 \mathrm{ml}$ PBS. The number of cells in each sample was counted using a haemocytometer prior to the final spin and the cell pellet was dissolved in $1 \mathrm{ml} 2 \%$ nitric acid for 2 days. Samples were analysed using a Perkin-Elmer NexION 300x ICP-MS with NexION software version 1.4. The gold amount was calculated against a standard curve of gold chloride plus washed cells. The amount of gold per cell was calculated for each sample by dividing the measured gold amount by the cell number.

TEM. 100000 cells per well were seeded onto 12-well transwell inserts overnight and then incubated with AuNPs for $3 \mathrm{~h}$ at a concentration of $10 \mu \mathrm{g} \mathrm{ml}{ }^{-1}$. Experiments with HSC-3 cells were repeated three times, each with technical duplicates (total $n=6$ ). Experiments with HaCaT cells were technical triplicates. Cells were fixed and AuNPs were silver enhanced for $45 \mathrm{~min}$ at room temperature (R-Gent, Aurion, Netherlands) and processed for imaging according to Gromnicova. ${ }^{15}$ Ultrathin sections of cells were visualized on a JEOL model $1010 \mathrm{EM}$ instrument operated at an accelerating voltage of $80 \mathrm{kV}$ at $\times 15000$ and $\times 50000$ magnifications. Only isolated cells were counted. It should be noted that silver enhancement increases the size of the nanoparticles, making them easier to detect in cell sections.

\section{Nanoparticle TEM counts on cells}

A systematic sampling method was used to evaluate nanoparticle counts in cells. This method was based on acquiring 25 TEM images at the same magnification and same settings across every sample at regular intervals, which included every fifth field of view of a cell. Each image was loaded into ImageJ software (NIH), where the visible areas of the nucleus and cytoplasm, and the length of the cell surface were measured, and the numbers of nanoparticles in each of these three regions were manually counted. Data are expressed as nanoparticles per micron ${ }^{2}$ for nuclear and cytoplasmic nanoparticle counts, and as nanoparticles per micron for cell surface nanoparticle counts.

\section{Fascin inhibition}

The fascin inhibitor fascin-G2 (Xcessbio, M60269-2s) was used to inhibit filopodia formation. Cells were incubated with $50 \mu \mathrm{M}$ fascin-G2 for $2 \mathrm{~h}$ at $37^{\circ} \mathrm{C}$. Then cells were incubated with $10 \mu \mathrm{g}$ $\mathrm{ml}^{-1}$ AuNPs in $50 \mu \mathrm{M}$ fascin-G2 for a further $3 \mathrm{~h}$, either at $37^{\circ} \mathrm{C}$ or at $4{ }^{\circ} \mathrm{C}$. Cells were then washed, fixed and prepared for TEM analysis.

\section{Caspase inhibition}

Cells were set up for clonogenic assay as described. Cells were pre-incubated with either $70 \mathrm{nM}$ caspase 8 inhibitor I (Merck, 218773) or $50 \mathrm{nM}$ caspase 9 inhibitor II (Merck, 218776) or caspase 3/7 inhibitor (Abcam, ab120382) for $1 \mathrm{~h}$ prior to addition of $10 \mu \mathrm{g} \mathrm{ml}^{-1}$ AuNPs and incubation for $3 \mathrm{~h} .10 \mu \mathrm{M}$ Antimycin A (Abcam, ab141904) was used as a positive control for apoptosis and $50 \mathrm{ng} \mathrm{ml}^{-1}$ Apo2 ligand/TRAIL as a positive control for inducing extrinsic apoptosis. Clonogenic assays were analysed after 6 days, as described. Experiments were repeated three times, each with technical triplicates (total $n=9$ ).

\section{Statistical analyses}

Data were analysed using GraphPad 6.0 Prism software. For cell work, multiple comparisons between many groups were performed by one-way ANOVA with Tukey's multiple comparison post-test; while comparison of the mean values between two groups was made by multiple two-tailed $t$-tests with a SidakBonferroni post-test. Comparison of $\mathrm{S}: \mathrm{Au}$ ratios, $\mathrm{O}: \mathrm{Au}$ ratios and $\mathrm{C}: \mathrm{Au}$ ratios were made using paired two-tailed $t$-tests.

\section{Results and discussion}

\section{Physico-chemical and solution stability characterisation}

TEM analysis revealed the short synthesis $(1 \mathrm{~h})$ and long synthesis ( $5 \mathrm{~h}$ ) AuNPs to be spherical with mean core diameters of $1.6 \pm 0.8 \mathrm{~nm}$ and $1.5 \pm 0.9 \mathrm{~nm}$, respectively (mean \pm SD; ESI Fig. $1 \dagger$ ). Consistent with this, the UV-vis spectra revealed no plasmon band, indicating a core diameter smaller than $2 \mathrm{~nm}$ (ref. 16) (ESI Fig. 2A $\dagger$ ). DLS analysis showed a hydrodynamic diameter of $4.6 \pm 0.9 \mathrm{~nm}$ for short synthesis AuNPs and $3.7 \pm$ $1.0 \mathrm{~nm}$ for long synthesis AuNPs (mean \pm SD; ESI Fig. 2B †). The zeta potential of the AuNPs at $\mathrm{pH} 7$ was positive at $43.8 \pm$ $16.4 \mathrm{mV}$ for short synthesis AuNPs (with some split peaks) and $41.8 \pm 10.6 \mathrm{mV}$ for long synthesis AuNPs (mean \pm SD; ESI Fig. $2 \mathrm{C} \dagger$ ). FPLC revealed no tendency to aggregate in PBS, with a single elution peak at $17.97 \mathrm{ml}$ for short synthesis AuNPs and at $17.99 \mathrm{ml}$ for long synthesis AuNPs (ESI Fig. 2D广்).

${ }^{1} \mathrm{H}$-NMR demonstrated an $\alpha$-galactose : PEGamine ligand ratio of $53: 47$ for short synthesis AuNPs and $51: 49$ for long synthesis AuNPs (ESI Fig. $3 \dagger$ ).

SEM-EDS analysis demonstrated a significant $\sim 15 \%$ decrease in the $\mathrm{S}: \mathrm{Au}$ ratio from $0.1013 \pm 0.0011$ for short synthesis AuNPs to $0.0860 \pm 0.0018$ for long synthesis AuNPs (mean $\pm \mathrm{SD}, P=0.0001, n=5$ areas analysed per sample; ESI Fig. $4 \uparrow$ ), consistent with a loss of sulphur-bearing ligands. The ratios of $\mathrm{O}: \mathrm{Au}$ and $\mathrm{C}: \mathrm{Au}$ in these analysed regions also significantly decreased with increasing AuNP synthesis time, consistent with a loss of ligands $(\mathrm{O}: \mathrm{Au} 0.1720 \pm 0.0035$ for short synthesis AuNPs to $0.1414 \pm 0.0025$ for long synthesis AuNPs; mean $\pm \mathrm{SD}, P=0.0001, n=5$. C : Au $0.3365 \pm 0.0091$ for short synthesis AuNPs to $0.2819 \pm 0.0114$ for long synthesis AuNPs; mean \pm SD, $P=0.0006, n=5$. ESI Fig. $4 \dagger$ ). 
HPLC analysis similarly demonstrated a loss of ligands from the AuNPs with increasing reaction time (ESI Fig. $5 \dagger$ ). Thus, short synthesis AuNPs had 40.8 ligands per $100 \mathrm{Au}$ atoms, while long synthesis AuNPs had 34.8 ligands per $100 \mathrm{Au}$ atoms (a decrease of $\sim 15 \%$, consistent with SEM-EDS). A previous study has determined that $1.52 \mathrm{~nm}$ core diameter AuNPs contain an average of $116 \mathrm{Au}$ atoms. ${ }^{17}$ This is within the size range of our AuNPs, as determined by TEM. Therefore, the HPLC values of ligands per $100 \mathrm{Au}$ atoms approximate the actual number of ligands per AuNP. Interestingly, our data are similar to those of Jadzinsky et al. ${ }^{18}$ in which AuNPs comprising 102 gold atoms were found to be surrounded by 44 thiol ( $p$-mercaptobenzoic acid) ligands.

In agreement with our ${ }^{1} \mathrm{H}-\mathrm{NMR}$ data, the HPLC data demonstrated that the $\alpha$-galactose : PEGamine ligand ratio remained stable during AuNP synthesis (53:47 for short synthesis AuNPs and 52:48 for long synthesis AuNPs; ESI Fig. $5 \dagger$ ).

How are ligands being removed from AuNPs during synthesis? Above a concentration of $24 \mathrm{mM}, \mathrm{NaBH}_{4}$ has been shown to strip all ligands from readily formed $>10 \mathrm{~nm}$ AuNPs within $10 \mathrm{~min}$, while at lower $\mathrm{NaBH}_{4}$ concentrations, desorption becomes less effective $(<30 \%$ desorption using $8 \mathrm{mM} \mathrm{NaBH}$ and no desorption using $\left.0.5 \mathrm{mM} \mathrm{NaBH}_{4}\right) .{ }^{19}$ No similar study has examined the kinetics of ligand desorption during AuNP formation. Two ways in which $\mathrm{NaBH}_{4}$ could be quenched in the reaction are via hydrolysis or reaction with disulphide bonds. The former possibility is unlikely, since although $\mathrm{NaBH}_{4}$ is hydrolysed within seconds at low $\mathrm{pH}$, it is stable for days at high $\mathrm{pH}$ and our reaction $\mathrm{pH}$ remains alkaline, falling from $\mathrm{pH} 12$ to $\mathrm{pH} 11.5$ in $5 \mathrm{~h}$. The second possibility is that a portion of the $\mathrm{NaBH}_{4}$ is lost as it reduces the gold salt and the disulphide bonds of the ligands. We therefore measured the $\mathrm{NaBH}_{4}$ concentration during AuNP synthesis and found that it decreased logarithmically from $90 \mathrm{mM}$ before adding the reactants to $6 \mathrm{mM}$ after $5 \mathrm{~h}$. Importantly, the $\mathrm{NaBH}_{4}$ concentration fell below $24 \mathrm{mM}$ within 35-40 min (ESI Fig. 6†). However, the same reaction in the absence of disulphides did not demonstrate any dramatic decrease in $\mathrm{NaBH}_{4}$ concentration for $5 \mathrm{~h}$ (not shown). Thus, in our usual synthesis reaction, a low concentration of $\mathrm{NaBH}_{4}$ persists in solution for several hours and this could set up a dynamic equilibrium between ligand desorption and resorption that favours a slow overall desorption of the more weakly bound ligands from the AuNPs.

\section{Clonogenic assay}

The cytotoxic/cytostatic potential of acute $(3 \mathrm{~h})$ exposure of HSC3 cells to AuNPs was determined by clonogenic assay and showed a dose-dependent reduction in cell colonies. Short synthesis AuNPs had an $\mathrm{IC}_{50}$ of around $8 \mu \mathrm{g} \mathrm{ml}^{-1}$, while long synthesis AuNPs had an $\mathrm{IC}_{50}$ of around $3.5 \mu \mathrm{g} \mathrm{ml}{ }^{-1}$ (Fig. 1).

\section{Cellular uptake and distribution of AuNPs}

Total cellular uptake of AuNPs, which includes AuNPs both on and within cells, was determined by ICP-MS on low-density cell cultures (to permit the unimpeded extension of filopodia around each cell). Cells were found to accumulate similar

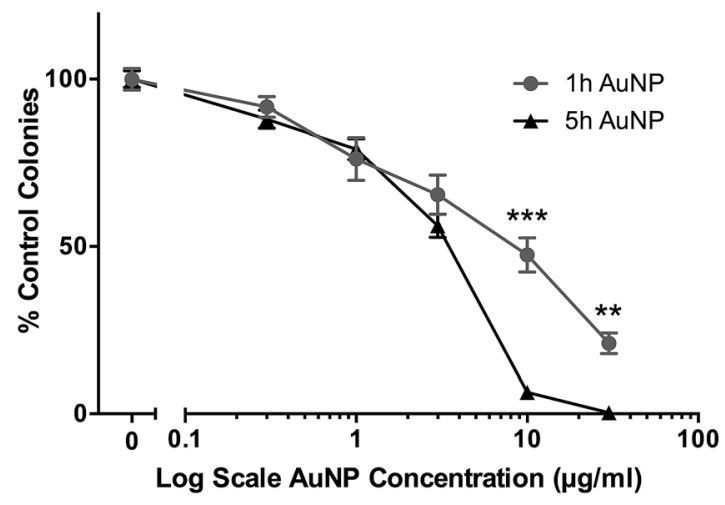

Fig. 1 Clonogenic assay of short synthesis ( $1 \mathrm{~h}$ ) and long synthesis (5 h) AuNPs on HSC -3 cells following $3 \mathrm{~h}$ acute exposure. All data are shown as mean \pm SEM. ${ }^{* *}=P<0.01,{ }^{* * *}=P<0.001, n=9$.

amounts of each type of AuNP within $3 \mathrm{~h}(4.8 \pm 1.8 \mathrm{pg}$ per cell for short synthesis AuNPs and $6.8 \pm 2.2$ pg per cell for long synthesis AuNPs; two-tailed $t$-test $P=0.63$ ).

To examine the details of AuNP cellular uptake, we used a well-established quantitative TEM method. ${ }^{15,20-22}$ To discriminate between energy-dependent and passive transport, cell uptake studies were performed at $37{ }^{\circ} \mathrm{C}$ or $4{ }^{\circ} \mathrm{C}$, respectively. Following $3 \mathrm{~h}$ incubation at $37{ }^{\circ} \mathrm{C}$, AuNPs were found predominantly within the cytoplasm, with no significant differences between the accumulation of short synthesis or long synthesis AuNPs (Fig. 2), consistent with the ICP-MS data. However, when incubated instead at $4{ }^{\circ} \mathrm{C}$, there was a dramatic shift in the distribution of both AuNPs to the cell surface, with significantly more long synthesis AuNPs being associated with the cell surface than short synthesis AuNPs (Fig. 3). At $4{ }^{\circ} \mathrm{C}$ AuNPs were not randomly distributed on the cell surface, but instead were preferentially associated with filopodia (88.9\% (3385/3808) of long synthesis AuNPs and 82.5\% (2254/2732) of short synthesis AuNPs at the cell surface were associated with filopodia; Fig. 3B and $\mathrm{C}$ ).

Previous studies have shown that varying the ligand density affects nanoparticle cellular accumulation, although there is no consensus on whether low or high ligand density is optimal..$^{7-10}$ Moreover, the precise distribution of ligands on the nanoparticle surface may be crucial, since computer simulations indicate that a homogeneous ligand distribution favours cellular uptake, while the presence of ligand-free areas prevents cellular uptake. ${ }^{23}$ However, in this study, AuNP intracellular accumulation was not significantly affected by ligand density, although binding to the cell surface was better with lower ligand density AuNPs.

To confirm whether AuNPs were selectively binding to filopodia, HSC-3 cells were pre-incubated with fascin-G2, an inhibitor of the actin bundling ability of fascin, that thereby destabilizes filopodia and prevents their formation. Fascin inhibition resulted in $85 \%$ fewer filopodia per micron of the cell surface (compare Fig. 4A and D with Fig. 4B, C, E and $\mathrm{F}$ ).

Following fascin inhibition, cells loaded with short synthesis or long synthesis AuNPs at $4{ }^{\circ} \mathrm{C}$ demonstrated a significant 

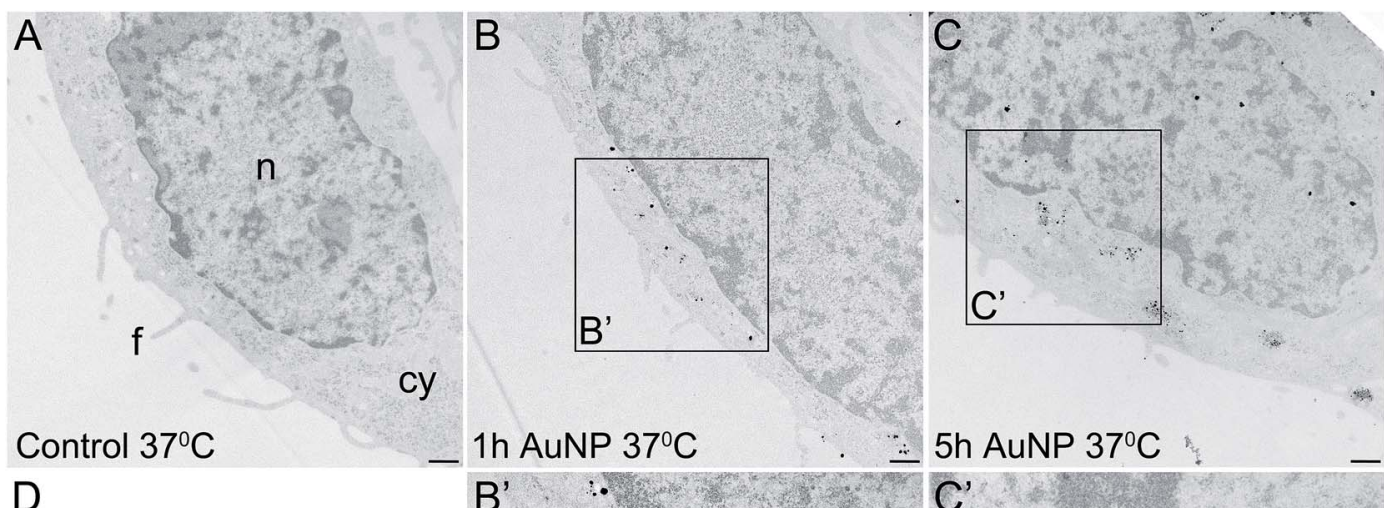

cy

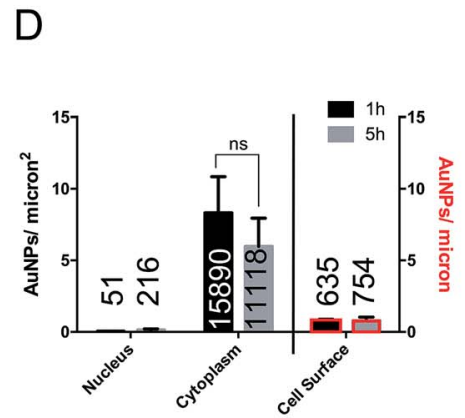

1h AuNP $37^{\circ} \mathrm{C}$

5h AuNP $37^{\circ} \mathrm{C}$

$B^{\prime}$
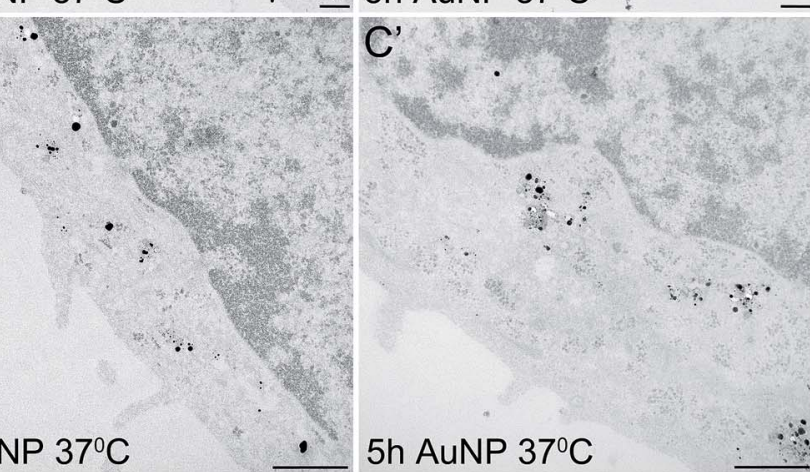

Fig. 2 TEM images of silver enhanced HSC-3 cells after acute 3 h exposure to $10 \mu \mathrm{g} \mathrm{ml}^{-1} \mathrm{AuNPs}$ at $37^{\circ} \mathrm{C}$. (A) No AuNP control. (B) Short synthesis $(1 \mathrm{~h})$ AuNPs. (C) Long synthesis ( $5 \mathrm{~h})$ AuNPs. $\left(\mathrm{B}^{\prime}\right)$ and $\left(\mathrm{C}^{\prime}\right)$ show magnified portions of the boxed regions of $(B)$ and $(C)$, respectively. $n=$ nucleus, $c y$ $=$ cytoplasm, $\mathrm{f}=$ filopodia. Scale bars $=500 \mathrm{~nm}$. (D) Quantitation of AuNP counts per micron ${ }^{2}$ for the nucleus and cytoplasm (left axis) and AuNP counts per micron for the cell surface (right axis, bars with red border). Total numbers of AuNPs counted per category are shown on bars. All data are shown as mean $\pm \mathrm{SEM}, n=6$.
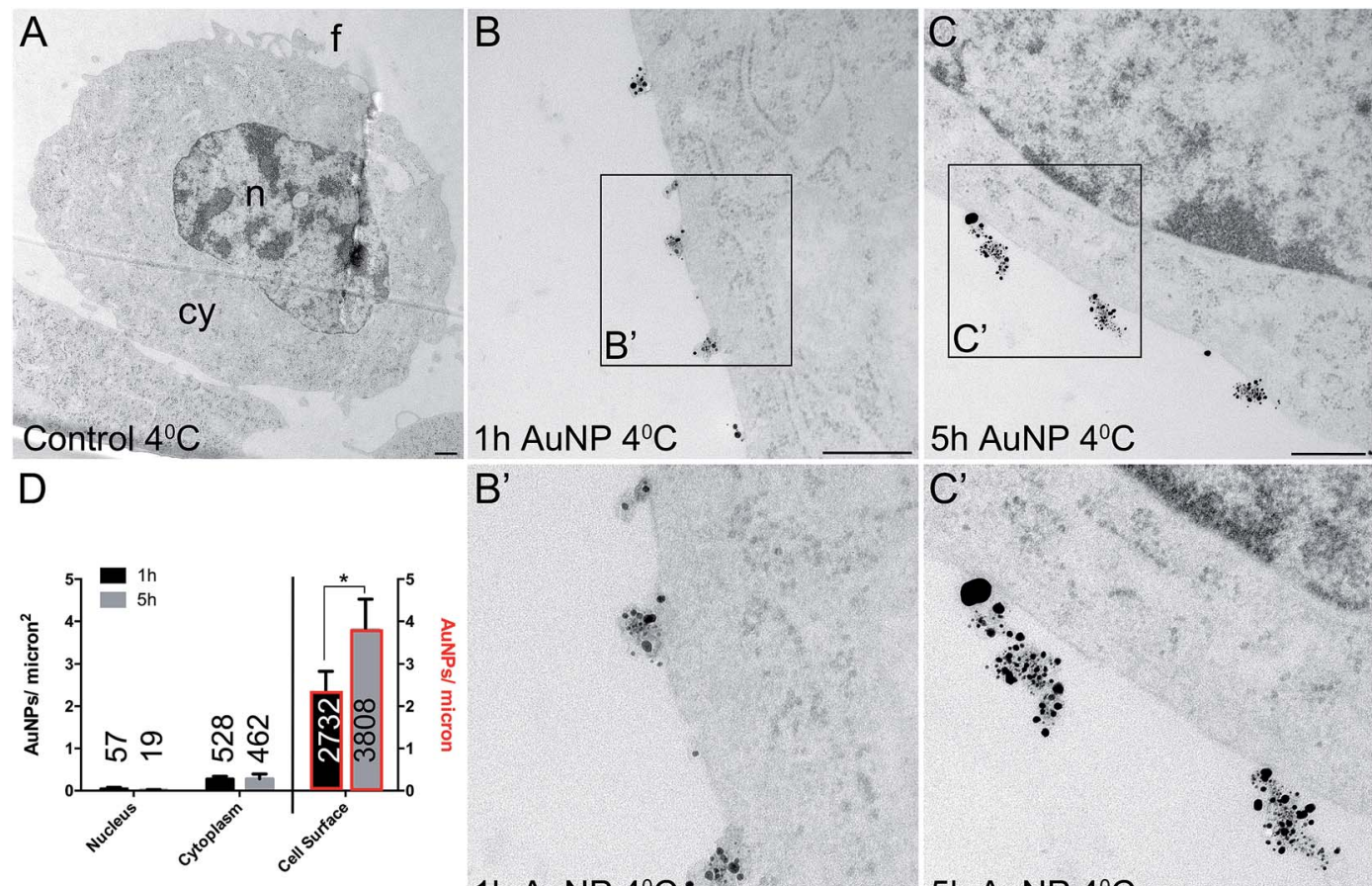

5h AuNP $4^{\circ} \mathrm{C}$
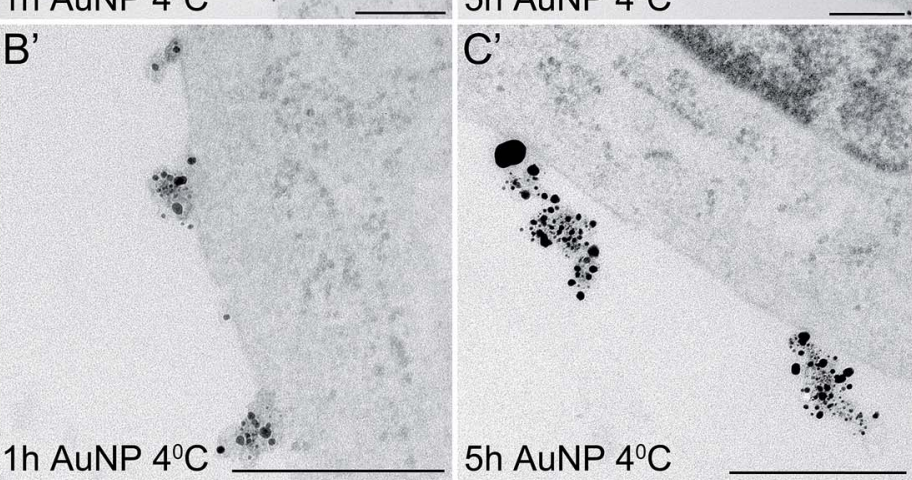

Fig. 3 TEM images of silver enhanced HSC-3 cells after acute $3 \mathrm{~h}$ exposure to $10 \mu \mathrm{g} \mathrm{ml} \mathrm{l}^{-1}$ AuNPs at $4{ }^{\circ} \mathrm{C}$. (A) No AuNP control. (B) Short synthesis $(1 \mathrm{~h})$ AuNPs. (C) Long synthesis ( 5 h) AuNPs. $\left(B^{\prime}\right)$ and $\left(C^{\prime}\right)$ show magnified portions of the boxed regions of $(B)$ and $(C)$, respectively. $n=$ nucleus, $c y$ $=$ cytoplasm, $f=$ filopodia. Scale bars $=500 \mathrm{~nm}$. (D) Quantitation of AuNP counts per micron ${ }^{2}$ for the nucleus and cytoplasm (left axis) and AuNP counts per micron for the cell surface (right axis, bars with red border). Total numbers of AuNPs counted per category are shown on bars. All data are shown as mean \pm SEM. $*=P<0.05, n=6$. 

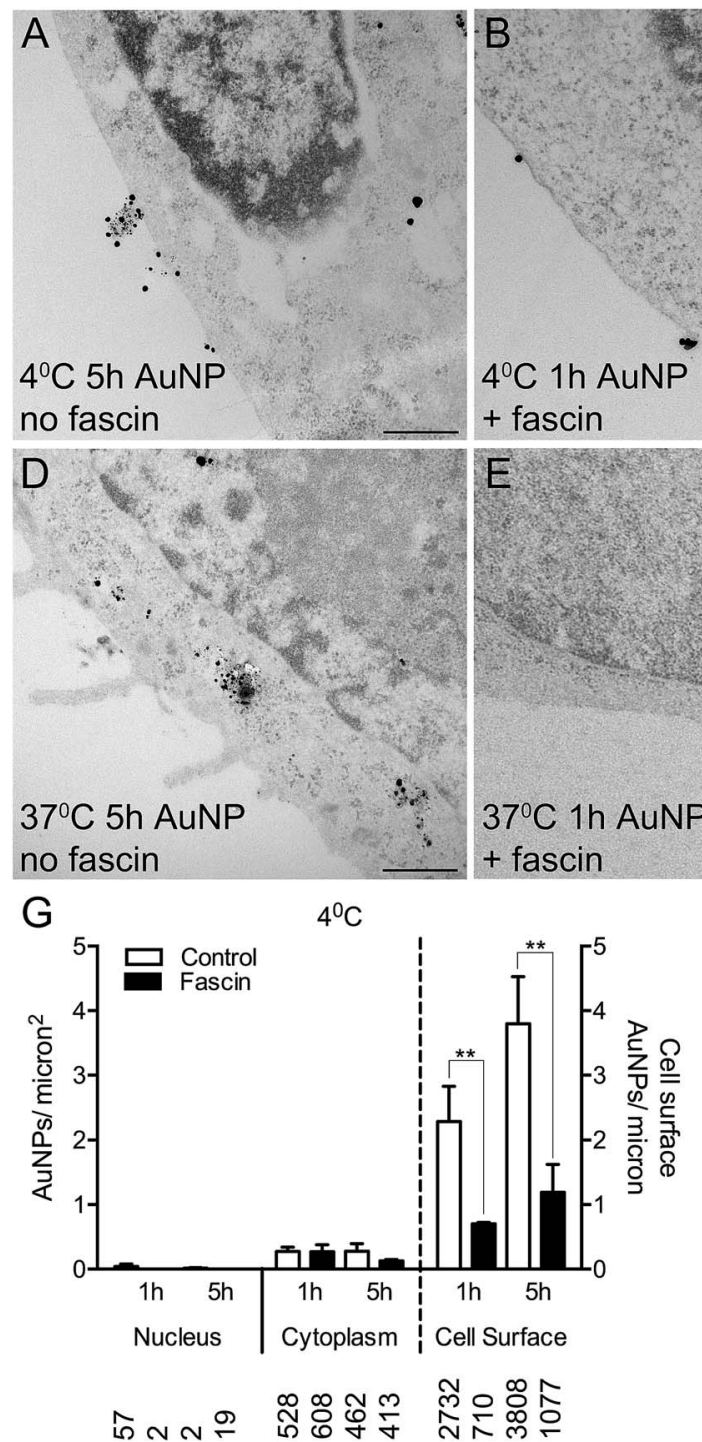
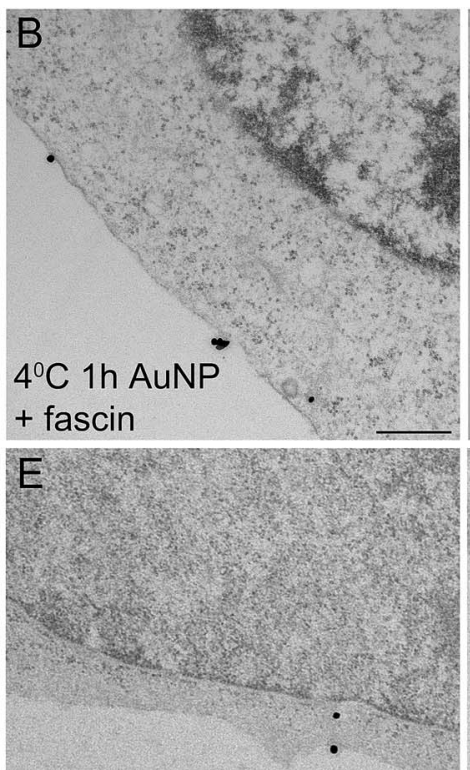

$37^{\circ} \mathrm{C}$ 1h AuNP + fascin
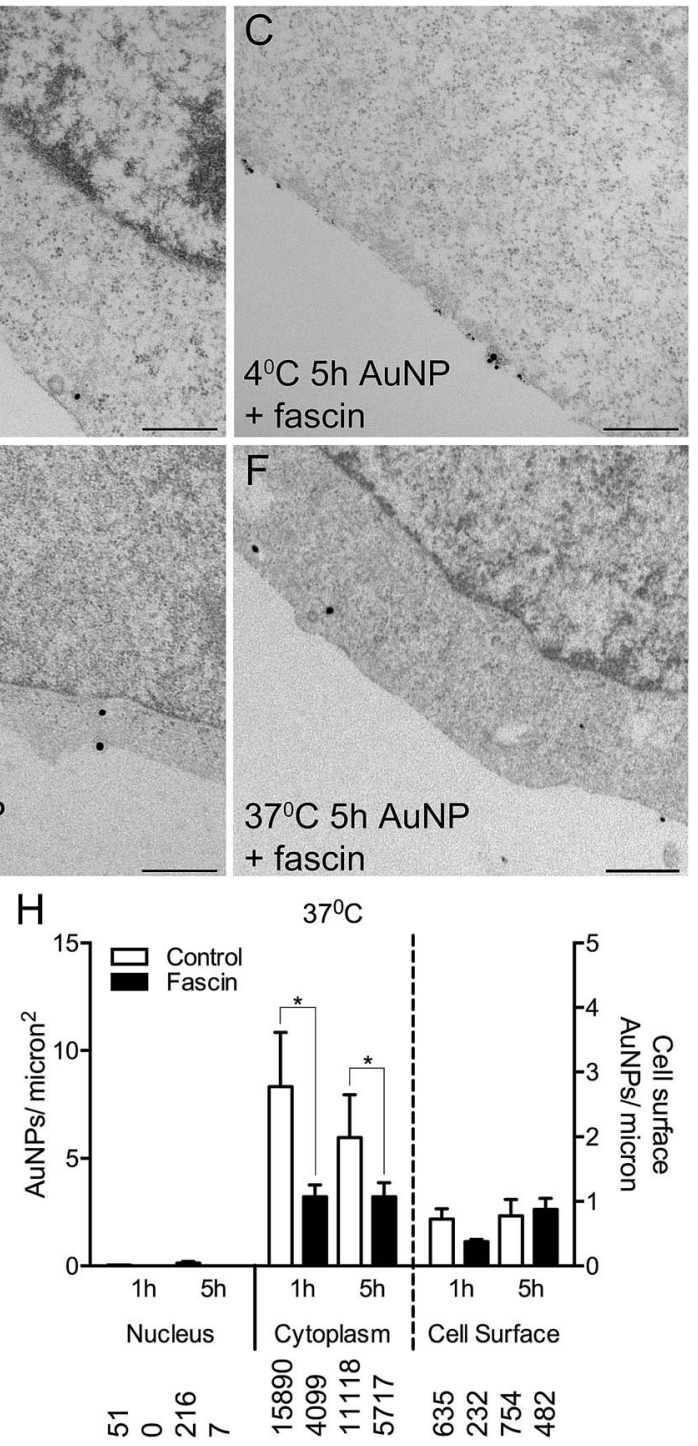

Fig. 4 (A-F) TEM images of silver enhanced HSC-3 cells incubated for $3 \mathrm{~h}$ with $10 \mu \mathrm{g} \mathrm{ml} \mathrm{l}^{-1}$ AuNPs at $4^{\circ} \mathrm{C}$ in (A) the absence or (B, C) the presence of a fascin inhibitor or at $37^{\circ} \mathrm{C}$ in (D) the absence or (E, F) the presence of a fascin inhibitor. Scale bars $=500 \mathrm{~nm}$. (G, H) Quantitation of AuNP counts per micron ${ }^{2}$ for the nucleus and cytoplasm (left axis) and AuNP counts per micron for the cell surface (right axis) with or without a fascin inhibitor at either $(\mathrm{G}) 4^{\circ} \mathrm{C}$ or $(\mathrm{H}) 37^{\circ} \mathrm{C}$. Total numbers of AuNPs counted per category are shown below bars. All data are shown as mean \pm SEM. * $=P<0.05, * *=P<0.01, n=6$.

three-fold reduction of AuNPs at the cell surface (Fig. 4G), while cells loaded with short synthesis or long synthesis AuNPs at $37^{\circ} \mathrm{C}$ demonstrated significantly fewer AuNPs within the cytoplasm (Fig. 4H).

\section{AuNP interactions with other cell lines}

In order to determine if there were any obvious trends in the way that long synthesis AuNPs interact with cell membranes, we examined two additional cell types: hCMEC/D3 human endothelial cells and HaCaT human keratinocytes.

First, we examined whether incubation at $4{ }^{\circ} \mathrm{C}$ resulted in an inhibition of cellular uptake and a redistribution of AuNPs to the cell surface. As shown in Fig. 4, the uptake of $10 \mu \mathrm{g} \mathrm{ml}^{-1}$ long synthesis AuNPs into HSC-3 cells is inhibited by $95 \%$ if the incubation is performed at $4{ }^{\circ} \mathrm{C}$ (mean cytoplasmic AuNPs: 5.97 $\pm 1.97 / \mu \mathrm{m}^{-2}$ at $37^{\circ} \mathrm{C}$ versus $0.28 \pm 0.12 / \mu \mathrm{m}^{-2}$ at $4{ }^{\circ} \mathrm{C}$, Fig. $4 \mathrm{G}$ and $\mathrm{H}$ ). The accumulation of $10 \mu \mathrm{g} \mathrm{ml}^{-1}$ long synthesis AuNPs into HaCaT cells was similarly inhibited by $94 \%$ when the incubation was performed at $4{ }^{\circ} \mathrm{C}$ (mean cytoplasmic AuNPs: $7.39 \pm 1.02 / \mu^{-2}$ at $37^{\circ} \mathrm{C}$ versus $0.43 \pm 0.12 / \mu \mathrm{m}^{-2}$ at $4{ }^{\circ} \mathrm{C}$; ESI Fig. $7 \mathrm{~A}$ and $\mathrm{B} \dagger$ ). Finally, under conditions comparable to those used here, we previously reported that the accumulation of $8 \mu \mathrm{g}$ $\mathrm{ml}^{-1}$ long synthesis AuNPs into hCMEC/D3 cells for $3 \mathrm{~h}$ is inhibited by $98 \%$ if the incubation is instead performed at $4{ }^{\circ} \mathrm{C} .{ }^{13}$

Next, we focussed on the proportion of long synthesis AuNPs associated with filopodia on the cell surface at $4{ }^{\circ} \mathrm{C}$. As mentioned above, HSC- 3 cells exhibit $88.9 \%$ association of AuNPs with filopodia at $4{ }^{\circ} \mathrm{C}$ (3385 AuNPs on filopodia of 3808 
total AuNPs on the cell surface). In contrast, HaCaT cells exhibit $52.5 \%$ association of AuNPs with filopodia at $4{ }^{\circ} \mathrm{C}(519$ AuNPs on filopodia of 988 total AuNPs on the cell surface, ESI Fig. $7 \mathrm{~B} \dagger$ ). A novel re-analysis of our existing TEM data for hCMEC/D3 cells at $4{ }^{\circ} \mathrm{C}$ (ref. 13) showed $11.9 \%$ association of AuNPs with filopodia (78 AuNPs on filopodia of 657 total AuNPs on the cell surface, ESI Fig. 7C and $\mathrm{D}^{\dagger}$ ).

From this limited dataset, it is possible to see a trend whereby the proportion of AuNPs associated with filopodia on the cell surface correlates with toxicity. Thus, HSC-3: 88.9\% filopodia binding, $\mathrm{IC}_{50} 3.5 \mu \mathrm{g} \mathrm{ml}{ }^{-1}$; HaCaT: 52.5\% filopodia binding, $\mathrm{IC}_{50} 10$ $\mu \mathrm{g} \mathrm{ml} \mathrm{m}^{-1}$ (ESI Fig. 7E $\dagger$ ); and hCMEC/D3: 11.9\% filopodia binding, $\mathrm{IC}_{50}>75 \mu \mathrm{g} \mathrm{ml}{ }^{-1}$ (note that hCMEC/D3 does not grow clonogenically). However, AuNPs were non-toxic at $75 \mu \mathrm{g} \mathrm{ml}{ }^{-1}$ after continuous exposure for $48 \mathrm{~h}$ (ref. 13). These data suggest that filopodial binding may stimulate cell death receptor(s), and this possibility is further explored in the next section using HSC-3 cells.

This is the first unequivocal report of AuNPs interacting specifically with filopodia. On macrophages, bacterial particles are captured by the shaft of the filopodia and then directed towards the cell surface into phagocytic cups. ${ }^{24}$ Similarly, exosome nanovesicles attach to filopodia and become directed to endocytic hotspots at their base. ${ }^{25}$ AuNPs were only seen on filopodia at $4{ }^{\circ} \mathrm{C}$ when energy-dependent transport was inhibited; this suggests that at $37^{\circ} \mathrm{C}$ they are normally rapidly cleared and/or endocytosed. However, we have no evidence that the extent of filopodial binding is a predictor of subsequent uptake: they could be independent.

We cannot yet definitively state whether AuNPs initially bind to pre-existing filopodia or whether AuNP binding to the cell surface locally stimulates filopodia formation. A study involving silica nanoparticles found that the nanoparticle aspect ratio affected filopodia formation and pinocytosis. ${ }^{\mathbf{2 6}}$

One possibility is that these AuNPs are capable of binding to receptors expressed preferentially on filopodia, possibly in an analogous manner to the selective cancer cell targeting of some oncolytic viruses. ${ }^{27}$

Another possibility is that electrostatic interactions may occur between the positively charged AuNPs and the negatively charged cell membrane. ${ }^{28,29}$ Selectivity could arise due to variations in membrane potential, which can differ by up to $90 \mathrm{mV}$ between different cell types. ${ }^{28}$ It is currently unknown whether the membrane potential of filopodia is more negative than that of the other regions of the cell membrane. However, the curvature of the filopodial shaft is sculpted from within by negative charges on the convex surface of small, 'banana-shaped' intracellular proteins, which repel and bend the adjacent negatively charged cell membrane. ${ }^{30}$ Speculatively, this may locally increase the negative charge on the filopodia surface. Consistent with this idea, positively charged $1.4 \mathrm{~nm}$ "Nanogold" AuNPs appear to bind to filopodia more strongly than the rest of the cell membrane on fixed COS7 cells. ${ }^{31}$ Although the magnification used in that SEM study was unable to resolve individual AuNPs. The exact nature of the ligand shell on nanogold is proprietary, but the manufacturer states there are 6 primary amine groups per AuNP. ${ }^{32}$ This differs from the ligand structure of our AuNPs, disfavouring (but not disproving) the idea of a common filopodial receptor for both types of AuNPs and instead favouring the idea of an electrostatic contribution to AuNP binding to cell surfaces, with the exact distribution of AuNPs on each cell surface being determined by charge heterogeneities.

Independent of AuNP charge, the energy-independent insertion of AuNPs coated in amphiphilic organic ligands into the cell membrane lipid bilayer occurs preferentially in regions of high cell membrane curvature ${ }^{33}$ and is dramatically improved when the core size is below $3 \mathrm{~nm} .{ }^{34}$ Although these studies did not specifically examine filopodia, the tips and bases of filopodial protrusions and the small radius of the filopodial shaft all constitute highly curved regions of the cell membrane and could therefore act as preferential adhesion sites for nanoparticles capable of this kind of membrane insertion via 'snorkeling.' ${ }^{35}$ In the present study, the hexaethylene glycol portion of the PEGamine ligand may be sufficiently amphiphilic to allow such an energyindependent interaction with the cell membrane. Further detailed studies will be required to compare the filopodial binding and cellular uptake of AuNPs using different ratios of $\alpha$ galactose : PEGamine. Our previous study ${ }^{2}$ demonstrated differences in uptake (assessed by ICP-MS) into HSC-3 and HaCaT cells as the $\alpha$-galactose : PEGamine ratio was varied. The highest uptake being seen with $50: 50$ ratio AuNPs $(50: 50>60: 40 \approx$ $40: 60 \approx 0: 100>100: 0$ ). However, we do not yet have any TEM data regarding the filopodial interactions of these different $\alpha$ galactose : PEGamine ratio AuNPs under energy-independent conditions, such as incubation at $4{ }^{\circ} \mathrm{C}$, and we have found no similar TEM study in the literature.

\section{AuNP toxicity is due to extrinsic apoptosis}

These studies were done using the more toxic, long synthesis AuNPs. Co-incubation of HSC-3 cells with AuNPs and a caspase 3/7 inhibitor prevented AuNP-induced cell death in clonogenic assays, confirming apoptosis (Fig. 5A).

To discriminate between classical caspase-dependent extrinsic and intrinsic apoptosis pathways, cells were coincubated with AuNPs and either a caspase 8 inhibitor (apical caspase in the extrinsic pathway) (Fig. 5B) or a caspase 9 inhibitor (apical caspase in the intrinsic pathway) (Fig. 5C). ${ }^{36}$ Caspase 9 inhibition had no effect on AuNP toxicity, while caspase 8 inhibition prevented AuNP toxicity, suggesting extrinsic apoptosis. In each case, cell death due to positive control apoptosis-inducing agents was prevented by the caspase inhibitors (Fig. 5). Note that each caspase inhibitor alone is slightly toxic and rescue of AuNP or positive control drug toxicity brings the cell viability back to the inhibitor-only value.

Nanoparticle toxicity, ${ }^{37}$ specifically AuNP toxicity, ${ }^{38}$ is usually reported to occur via mitochondrial ${ }^{37}$ or endoplasmic reticulum stress, ${ }^{39}$ leading to cleavage of caspase $9 .^{38,40}$ By contrast, nanoparticle-induced extrinsic apoptosis, due to caspase 8 cleavage, is rarely reported. Cleavage of caspase 8 and accumulation of FADD were seen in JB6 mouse skin cells within $1 \mathrm{~h}$ of adding tungsten carbide-cobalt nanoparticles, ${ }^{\mathbf{4 1}}$ while cleavage of caspase 8 was seen in human keratinocyte HaCaT cells within $6 \mathrm{~h}$ of adding titanium dioxide nanoparticles. ${ }^{42}$ 

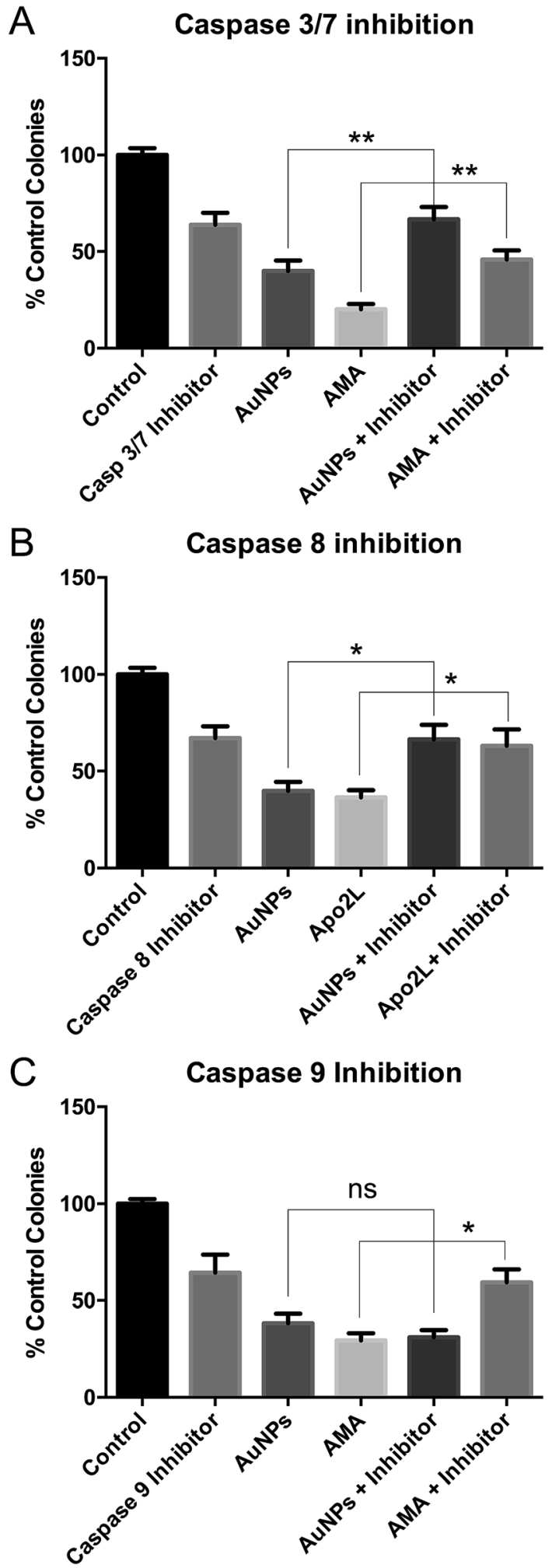

Fig. 5 Clonogenic assays of HSC -3 cells treated with long synthesis time AuNPs or apoptosis-inducing drugs and inhibitors of (A) caspase $3 / 7$ or (B) caspase 8 or (C) caspase 9 . All are data shown as mean \pm SEM. ns $=$ not significant. ${ }^{*}=P<0.05, * *=P<0.01, n=9$.

However, to our knowledge, extrinsic apoptosis has not been reported before with AuNPs. We do not claim that there is anything particularly unusual about our AuNPs that leads to extrinsic apoptosis, simply that most papers demonstrating AuNP-induced apoptosis only look at caspase 3 activation (reviewed in ref. 38).

It is tempting to link our observations of increased filopodial binding of AuNPs with extrinsic apoptosis. However, our data do not yet allow us to conclude that excessive filopodial binding causes apoptosis. Future work will determine whether these, currently independent, observations are linked.

For instance, it is not known whether any of the death receptors (TNFr, TRAMP, Fas, or DRs 4 to 6$),{ }^{43}$ which locally cleave and activate caspase 8 , are concentrated within filopodia and could thereby become activated by excessive or prolonged AuNP binding. It is nonetheless intriguing that increased filopodial density is often reported in cancer cells, ${ }^{44}$ being important for tumour progression, migration and dissemination. ${ }^{\mathbf{4 4 , 4 5}}$ Moreover, caspase 8 is associated with cell migration in cancer cells, ${ }^{46}$ being specifically associated with focal adhesion complexes, ${ }^{47}$ raising the possibility that caspase 8 may also be concentrated within filopodia.

Once inside cells, AuNPs can damage or impair the function of various organelles (reviewed in ref. 48), including lysosomes, ${ }^{49}$ mitochondria ${ }^{50}$ and the nucleus. ${ }^{12}$ AuNPs can also activate metal exposure and oxidative stress signalling pathways, ${ }^{11}$ resulting in autophagy. ${ }^{\mathbf{1}}$

AuNP-induced cell death is therefore likely to be multifactorial, with distinct temporal sequences of events converging via several pathways to kill the cell.

\section{Conclusions}

We have identified that $50: 50 \propto$-galactose : PEGamine AuNPs accumulate to differing extents on the filopodia of various cell types when energy-dependent uptake is prevented. These data provide a fascinating insight into how AuNPs initially interact with cell membranes and how the extent of filopodial interaction may be a deciding factor in the initiation of extrinsic death pathways. It will now be important to survey a large number of normal and diseased cell types to determine whether there is a correlation between how AuNPs interact with cell membranes and resulting cell behaviours, not limited to cell death.

Nanoparticle synthesis time is rarely reported in the literature. Our observation that longer synthesis time AuNPs are more adherent to HSC- 3 cell membranes and are more toxic than short synthesis AuNPs underscores that future publications would be wise to routinely quote synthesis time.

From a practical perspective, our data suggest that by varying the synthesis time, AuNPs could be engineered for either enhanced or reduced toxicity, depending on the desired application.

\section{Conflicts of interest}

There are no conflicts to declare.

\section{Acknowledgements}

Konstantina Tzelepi was funded by a joint grant from Midatech Pharma and the Open University. We thank Dr Radka 
Gromnicova and Gordon Imlach at the Open University for preparing sections for TEM and performing SEM-EDS, respectively. We additionally thank Dr Radka Gromnicova and Professor David Male at the Open University for sharing unpublished TEM images of hCMEC/D3 cells.

\section{References}

1 S. Behzadi, V. Serpooshan, W. Tao, M. A. Hamaly, M. Y. Alkawareek, E. C. Dreaden, D. Brown, A. M. Alkilany, O. C. Farokhzad and M. Mahmoudi, Chem. Soc. Rev., 2017, 46, 4218-4244.

2 S. Grellet, K. Tzelepi, M. Roskamp, P. Williams, A. Sharif, R. Slade-Carter, P. Goldie, N. Whilde, M. A. Smialek, N. J. Mason and J. P. Golding, PLoS One, 2017, 12, e0181103. 3 C. S. Yah, Biomed. Res., 2013, 24, 400-413.

4 A. M. Alkilany and C. J. Murphy, J. Nanopart. Res., 2010, 12, 2313-2333.

5 B. D. Chithrani, A. A. Ghazani and W. C. W. Chan, Nano Lett., 2006, 6, 662-668.

6 C. M. Goodman, C. D. McCusker, T. Yilmaz and V. M. Rotello, Bioconjugate Chem., 2004, 15, 897-900.

7 T. Lund, M. F. Callaghan, P. Williams, M. Turmaine, C. Bachmann, T. Rademacher, I. M. Roitt and R. Bayford, Biomaterials, 2011, 32, 9776-9784.

8 H. Liu, T. L. Doane, Y. Cheng, F. Lu, S. Srinivasan, J.-J. Zhu and C. Burda, Part. Part. Syst. Charact., 2015, 32, 197-204.

9 D. R. Elias, A. Poloukhtine, V. Popik and A. Tsourkas, Nanomedicine, 2013, 9, 194-201.

10 D. H. M. Dam, R. C. Lee and T. W. Odom, Nano Lett., 2014, 14, 2843-2848.

11 E. Bajak, M. Fabbri, J. Ponti, S. Gioria, I. Ojea-Jiménez, A. Collotta, V. Mariani, D. Gilliland, F. Rossi and L. Gribaldo, Toxicol. Lett., 2015, 233, 187-199.

12 M. Tsoli, H. Kuhn, W. Brandau, H. Esche and G. Schmid, Small, 2005, 1, 841-844.

13 R. Gromnicova, M. Kaya, I. A. Romero, P. Williams, S. Satchell, B. Sharrack and D. Male, PLoS One, 2016, 11, e0161610.

14 B. Elamin and G. E. Means, Anal. Chim. Acta, 1979, 107, 405409.

15 R. Gromnicova, H. A. Davies, P. Sreekanthreddy, I. A. Romero, T. Lund, I. M. Roitt, J. B. Phillips and D. K. Male, PLoS One, 2013, 8, e81043.

16 G. L. Nealon, B. Donnio, R. Greget, J.-P. Kappler, E. Terazzi and J.-L. Gallani, Nanoscale, 2012, 4, 5244.

17 M. J. Hostetler, J. E. Wingate, C.-J. Zhong, J. E. Harris, R. W. Vachet, M. R. Clark, J. D. Londono, S. J. Green, J. J. Stokes, G. D. Wignall, G. L. Glish, M. D. Porter, N. D. Evans and R. W. Murray, Langmuir, 1998, 14, 17-30.

18 P. D. Jadzinsky, G. Calero, C. J. Ackerson, D. A. Bushnell and R. D. Kornberg, Science, 2007, 318, 430-433.

19 S. M. Ansar, F. S. Ameer, W. Hu, S. Zou, C. U. Pittman and D. Zhang, Nano Lett., 2013, 13, 1226-1229.

20 A. Elsaesser, C. A. Barnes, G. McKerr, A. Salvati, I. Lynch, K. A. Dawson and C. V. Howard, Nanomedicine, 2011, 6, 1189-1198.
21 A. P. Brown, R. M. D. Brydson and N. S. Hondow, J. Phys.: Conf. Ser., 2014, 522, 012058.

22 B. Rothen-Rutishauser, D. A. Kuhn, Z. Ali, M. Gasser, F. Amin, W. J. Parak, D. Vanhecke, A. Fink, P. Gehr and

C. Brandenberger, Nanomedicine, 2014, 9, 607-621.

23 V. Schubertová, F. J. Martinez-Veracoechea and R. Vácha, Soft Matter, 2015, 11, 2726-2730.

24 M. Horsthemke, A. C. Bachg, K. Groll, S. Moyzio, B. Müther, S. A. Hemkemeyer, R. Wedlich-Söldner, M. Sixt, S. Tacke, M. Bähler and P. J. Hanley, J. Biol. Chem., 2017, 292, 72587273.

25 W. Heusermann, J. Hean, D. Trojer, E. Steib, S. von Bueren, A. Graff-Meyer, C. Genoud, K. Martin, N. Pizzato, J. Voshol, D. V. Morrissey, S. E. L. Andaloussi, M. J. Wood and N. C. Meisner-Kober, J. Cell Biol., 2016, 213, 173-184.

26 H. Meng, S. Yang, Z. Li, T. Xia, J. Chen, Z. Ji, H. Zhang, X. Wang, S. Lin, C. Huang, Z. H. Zhou, J. I. Zink and A. E. Nel, ACS Nano, 2011, 5, 4434-4447.

27 P. K. Singh, J. Doley, G. R. Kumar, A. P. Sahoo and A. K. Tiwari, Indian J. Med. Res., 2012, 136, 571-584.

28 M. Yang and W. J. Brackenbury, Front. Physiol., 2013, 4, 185.

29 E. C. Cho, J. Xie, P. A. Wurm and Y. Xia, Nano Lett., 2009, 9, 1080-1084.

30 S. H. Lee, F. Kerff, D. Chereau, F. Ferron, A. Klug and R. Dominguez, Structure, 2007, 15, 145-155.

31 H. Nishiyama, K. Teramoto, M. Suga and C. Sato, Microsc. Res. Tech., 2014, 77, 153-160.

32 Positively charged nanogold (product 2022) Nanoprobes.com, http:/www.nanoprobes.com/ instructions/Inf2022.html, accessed 20 June 2018.

33 R. C. Van Lehn, M. Ricci, P. H. J. Silva, P. Andreozzi, J. Reguera, K. Voïtchovsky, F. Stellacci and A. AlexanderKatz, Nat. Commun., 2014, 5, 4482.

34 R. C. Van Lehn, P. U. Atukorale, R. P. Carney, Y.-S. Yang, F. Stellacci, D. J. Irvine and A. Alexander-Katz, Nano Lett., 2013, 13, 4060-4067.

35 A. K. Chamberlain, Y. Lee, S. Kim and J. U. Bowie, J. Mol. Biol., 2004, 339, 471-479.

36 S. Elmore, Toxicol. Pathol., 2007, 35, 495-516.

37 D.-D. Ma and W.-X. Yang, Oncotarget, 2016, 7, 40882-40903. 38 H. Sun, J. Jia, C. Jiang and S. Zhai, Int. J. Mol. Sci., 2018, 19, 754.

39 C. Noël, J.-C. Simard and D. Girard, Toxicol. Vitro, 2016, 31, 12-22.

40 N. Morishima, K. Nakanishi, H. Takenouchi, T. Shibata and Y. Yasuhiko, J. Biol. Chem., 2002, 277, 34287-34294.

41 J. Zhao, J. Zhao, L. Bowman, L. Bowman, R. Magaye, R. Magaye, S. S. Leonard, S. S. Leonard, V. Castranova, V. Castranova, M. Ding and M. Ding, Int. J. Oncol., 2013, 42, 1349-1359.

42 C. Wright, A. K. V. Iyer, L. Wang, N. Wu, J. S. Yakisich, Y. Rojanasakul and N. Azad, Drug Chem. Toxicol., 2017, 40, 90-100.

43 H. Walczak, Cold Spring Harbor Perspect. Biol., 2013, 5, a008698.

44 A. Arjonen, R. Kaukonen and J. Ivaska, Cell Adhes. Migr., 2011, 5, 421-430. 
45 G. Jacquemet, H. Hamidi and J. Ivaska, Curr. Opin. Cell Biol., 2015, 36, 23-31.

46 R. P. Graf, N. Keller, S. Barbero and D. Stupack, Curr. Mol. Med., 2014, 14, 246-254.

47 S. Barbero, A. Mielgo, V. Torres, T. Teitz, D. J. Shields, D. Mikolon, M. Bogyo, D. Barilà, J. M. Lahti, D. Schlaepfer and D. G. Stupack, Cancer Res., 2009, 69, 3755-3763.

48 M. Kodiha, Y. M. Wang, E. Hutter, D. Maysinger and U. Stochaj, Theranostics, 2015, 5, 357-370.
49 X. Ma, Y. Wu, S. Jin, Y. Tian, X. Zhang, Y. Zhao, L. Yu and X.-J. Liang, ACS Nano, 2011, 5, 8629-8639.

50 Y. Pan, A. Leifert, D. Ruau, S. Neuss, J. Bornemann, G. Schmid, W. Brandau, U. Simon and W. Jahnen-Dechent, Small, 2009, 5, 2067-2076.

51 J. J. Li, D. Hartono, C.-N. Ong, B.-H. Bay and L.-Y. L. Yung, Biomaterials, 2010, 31, 5996-6003. 